\title{
PENGARUH PENGGUNAAN MODEL PROBLEM BASED LEARNING (PBL) UNTUK MENINGKATKAN PEMAHAMAN PESERTA DIDIK PADA MATERI PENCEMARAN LINGKUNGAN
}

\author{
Lilis Irawati \\ SMP N 3 Manonjaya, Jl. Pangangonan, Manonjaya, Tasikmalaya, Indonesia \\ Email: lira.muslih18@gmail.com
}

\begin{abstract}
There are still many seventh grade students of SMPN 3 Manonjaya who still neglect environment by littering. One of the causes is that the concept of enviromental pollution has not embedded yet in students. To overcome this matter, the writer tries to apply the model of Problem Based Learning (PBL) in conveying the concept of environmental pollution. Therefore, this classroom action research is aimed at increasing the understanding of students in class VII B SMPN 3 Manonjaya on the environmental pollution material using the model of PBL. This action research involves 32 students utilizing the techniques of data collection tools such as literature studies and observational data. The results show that : a) the enhancement of cognitive aspects is evidenced by an increase in the percentage of students who reached the $K K M$; b) there is an increase of students affective aspect during working in groups of making reports; c) there is an improvement of students' psychomotor aspects at the time of presentating the result of group work; and d) there is an instilling students' habits to build their own knowledge, find out the concepts by themselves to improve the understanding of the material, and enables students to learns in groups.
\end{abstract}

Keywords: Problem Based Learning (PBL) Model, Students' Understanding, Environmental Pollution

\begin{abstract}
ABSTRAK
Masih banyak peserta didik kelas VII di SMPN 3 Manonjaya yang masih belum peduli dengan keadaan lingkungan karena masih membuang sampah sembarangan. Salah satu penyebabnya adalah tidak tertanamnya konsep yang dipelajari pada diri peserta didik mengenai pencemaran lingkungan. Untuk mengatasi hal tersebut penulis mencoba menerapkan model Problem Based Learning (PBL) dalam menyampaikan konsep pencemaran lingkungan. Oleh sebab itu penelitian tindakan kelas ini mempunyai tujuan untuk meningkatkan pemahaman peserta didik kelas VII B di SMPN 3 Manonjaya pada materi pencemaran lingkungan hidup dengan menggunakan model PBL. Subjek penelitian ini adalah 32 orang siswa. Teknik dan alat pengumpulan data yang digunakan dalam penelitian tindakan kelas ini adalah studi literatur dan data hasil pengamatan. Hasil penelitian menunjukkan bahwa: a) adanya peningkatan dalam aspek kognitif yang dibuktikan dengan adanya peningkatan prosentase peserta didik yang mencapai KKM; b) adanya peningkatan aspek afektif selama peserta didik bekerja kelompok membuat laporan; c) adanya peningkatan aspek psikomotor pada saat peserta didik melakukan presentasi hasil kerja kelompok; dan d) adanya penumbuhan kebiasaan peserta didik untuk dapat membangun sendiri pengetahuan, menemukan sendiri konsep untuk meningkatkan pemahaman materi, dan belajar secara kelompok.
\end{abstract}

Kata Kunci: Model Problem Based Learning (PBL), Pemahaman Peserta Didik, Pencemaran Lingkungan

Cara sitasi: Irawati, L. (2021). Pengaruh penggunaan model problem based learning (pbl) untuk meningkatkan pemahaman peserta didik pada materi pencemaran lingkungan. J-KIP (Jurnal Keguruan dan IImu Pendidikan), 2 (2), 21-26. 


\section{PENDAHULUAN}

Mata pelajaran IPA termasuk salah satu mata pelajaran yang mempunyai materi pokok yang berhubungan sangat erat dengan kehidupan peserta didik. Salah satu materi yang dipelajari di kelas tujuh semester genap tahun pelajaran 2018/2019 adalah tentang pencemaran lingkungan, setelah peserta didik mempelajari konsep tentang pencemaran lingkungan di mata pelajaran IPA, peserta didik diharapkan dapat mendeskripsikan macam-macam pencemaran lingkungan serta dapat mencegah dan menentukan solusi dalam mengatasi pencemaran lingkungan dalam kehidupan sehari hari.

Harapan tersebut belum dapat terpenuhi oleh peserta didik di SMPN 3 Manonjaya, terbukti masih banyak peserta didik khususnya kelas VII umumnya peserta didik di SMPN 3 Manonjaya yang masih belum peduli dengan keadaan lingkungan yakni masih membuang sampah sembarangan. Menurut pengamatan penulis salah satu penyebabnya adalah tidak tertanamnya konsep yang dipelajari pada diri peserta didik.

Pembelajaran adalah suatu proses yang terjadi antara guru dengan siswa (Rahman, Rusyana \& Yulisma, 2021). Oleh sebab itu, untuk mengatasi hal tersebut penulis mencoba menerapkan model Problem Based Learning (PBL) dalam menyampaikan konsep pencemaran lingkungan. Problem Based Learning (PBL) adalah salah satu model pembelajaran yang menggunakan masalah nyata yang tidak terstruktur dan bersifat terbuka sebagai konteks atau sarana bagi peserta didik untuk mengembangkan keterampilan, menyelesaikan masalah dan berpikir kritis serta membangun pengetahuan baru. Fauziah et al., (2014) menyatakan model pembelajaran PBL merupakan salah satu model pembelajaran yang dianggap memiliki karakteristik pembelajaran saintifik.

Dalam proses pembelajaran yang menggunakan model Problem Based Learning (pembelajaran berbasis masalah) peserta didik secara individual maupun kelompok menyelesaikan masalah nyata dengan menggunakan strategi atau pengetahuan yang telah dimiliki, proses tersebut memungkinkan peserta didik berlatih mengembangkan kemampuan berpikir kritis dan kemampuan menyelesaikan masalah serta membangun konsep, pengetahuan serta strategi tertentu yang menekankan peserta didik untuk secara aktif membangun pengetahuannya sendiri bukan menerimanya dalam bentuk jadi dari guru.

Dengan menemukan sendiri konsep, maka peserta didik akan mudah mengingat apa yang dipelajarinya. Mengingat materi pencemaran lingkungan merupakan salah satu materi yang dekat dengan kehidupan peserta didik dan perlu aplikasi dalam kehidupan sehari hari maka model Problem Based Learning (PBL) sangat cocok untuk dijadikan solusi dalam menyampaikan konsep pencemaran lingkungan sehingga pemahaman belajar peserta didik akan meningkat. Menurut Saputri \& Febriani (2017) pembelajaran sains biologi dengan menggunakan model Problem Based Learning (PBL) menekankan pada berpikir tingkat tinggi. Penerapan model PBL dapat meningkatkan hasil belajar kognitif siswa Menurut hasil penelitian (Rerung et al., 2017).

Oleh sebab itu penelitian tindakan kelas ini mempunyai tujuan meningkatkan pemahaman peserta didik kelas VII BSMPN 3 Manonjaya semester genap tahun pelajaran 2018/2019 dalam materi pencemaran lingkungan hidup dengan menggunakan model Problem Based Learning (PBL).

\section{METODE PENELITIAN}

Penelitian dilaksanakan dari tanggal 16 Januari 2019 sampai dengan tanggal 6 Maret 2019. Tempat penelitian di SMP N 3 Manonjaya semester genap tahun pelajaran 2018/2019. Jumlah siswa 32 orang kelas VII yang terdiri dari 18 orang laki-laki dan 14 orang perempuan. Teni Sri Erniawati guru mata pelajaran IPA kelas IX sebagai observer. Teknik dan alat pengumpul data yang digunakan dalam penelitian tindakan kelas ini adalah sebagai berikut: studi literatur, data hasil pengamatan (hasil tes kognitif, hasil observasi sikap, observasi psikomotor selama pembelajaran serta hasil kerja sama dengan observer). 
Kriteria ketuntasan minimal (KKM) untuk untuk kelas VII semester genap tahun pelajaran 2018/2019 di SMPN 3 Manonjaya adalah 68. Data kuantitatif diperoleh dari nilai tes kognitif tiap siklus. Data kualitatif diperoleh dari hasil observasi terhadap sikap dan hasil observasi terhadap psikomotor peserta didik selama proses pembelajaran.

Aspek yang ingin ditingkatkan dalam penelitian tindakan kelas konsep pencemaran lingkungan adalah pemahaman peserta didik, penulis mengukur pemahaman dari 3 aspek yaitu kognitif, apektif dan psikomotor. Indikator setiap aspeknya adalah sebagai berikut:

1. Aspek kognitif

a. Siklus I dikatakan berhasil apabila peserta didik yang mendapatkan nilai sama dengan KKM atau lebih mencapai $50 \%$.

b. Siklus II dikatakan berhasil apabila peserta didik yang mendapatkan nilai sama dengan KKM atau lebih mencapai $60 \%$

c. Siklus III dikatakan berhasil apabila peserta didik yang mendapatkan nilai sama dengan KKM mencapai $75 \%$ atau lebih.

2. Aspek apektif ( sikap )

a. Siklus I dikatakan berhasil apabila dari semua aspek yang di observasi salah satunya ada yang mencapai kriteria cukup.

b. Siklus II dikatakan berhasil apabila dari semua aspek yang di observasi salah satu aspek mencapai kriteria baik.

c. Siklus III dikatakan berhasil apabila dari semua aspek yang di observasi dua aspek mencapai kriteria baik.

3. Keterampilan Presentasi Kelompok

a. Siklus I dikatakan berhasil apabila dari semua aspek keterampilan yang diobservasi salah satu aspek mencapai kriteria baik.

b. Siklus II dikatakan berhasil apabila dari semua aspek keterampilan yang diobservasi dua aspek mencapai kriteria baik.

c. Siklus III dikatakan berhasil apabila dari semua aspek keterampilan yang diobservasi tiga aspek mencapai kriteria baik

Dengan kriteria keberhasilan sebagai berikut: 81 - 100 (baik sekali), 66 - 80 (baik), 56 - 65 (cukup), 41 - 55 (kurang), 0 - 40 (gagal).

\section{HASIL DAN PEMBAHASAN}

Penelitian Pelaksanaan penelitian tindakan kelas dilakukan sebanyak 3 siklus yang dilihat dari 3 aspek yaitu kognitif, apektif dan psikomotor. Hasilnya adalah sebagai berikut:

1. Aspek kognitif

Siklus I dari 32 orang peserta didik yang tuntas sebanyak 17 orang atau $53,125 \%$ sedangkan yang tidak tuntas sebanyak 15 orang atau $46,875 \%$. Siklus II yang tuntas sebanyak 20 orang atau $62,50 \%$ sedangkan yang tidak tuntas sebanyak 12 orang masih belum tuntas atau sebanyak $37,50 \%$, berarti dari siklus I ke siklus II aspek kognitif mengalami kenaikan sebesar $9,375 \%$. Pada saat siklus III dari 32 peserta didik, yang tuntas sebanyak 26 orang atau $81,25 \%$ sedangkan yang tidak tuntas sebanyak 6 orang atau 18,75\%. Berarti dari siklus II ke siklus III aspek kognitif mengalami kenaikan sebesar $18,75 \%$.

2. Aspek apektif

Penilaian sikap dilakukan dengan menggunakan jurnal dan daftar isian berupa angket, hasilnya adalah sebagai berikut: siklus I aspek suasana pertemuan saat pembelajaran mencapai $64,58 \%$, aspek topik yang dibahas mencapai $52,08 \%$ dan kegiatan yang diikuti mencapai $50,00 \%$, di siklus II suasana pertemuan saat pembelajaran mencapai $76,54 \%$, topik yang dibahas mencapai $71,61 \%$ dan kegiatan yang diikuti mencapai $70,37 \%$, .Sedangkan siklus III suasana pertemuan mencapai $89,58 \%$, topik yang dibahas mencapai $83,33 \%$ dan kegiatan 
yang diikuti mencapai $84,375 \%$. Melihat perolehan prosentase setiap aspek dari siklus I ke siklus II dan dari siklus II ke siklus III setiap aspek mengalami kenaikan.

3. Aspek psikomotor

Aspek psikomotor dinilai dari pelaksanaan presentasi hasil kerja kelompok, hasilnya adalah sebagai berikut: kebenaran isi siklus I mencapai $72,22 \%$, siklus II mencapai $77,77 \%$ siklus III mencapai $88,88 \%$. Kejelasan suara siklus I mencapai $61,11 \%$, siklus II mencapai $83,33 \%$, siklus III mencapai $88,88 \%$. Keruntutan penyampaian siklus I mencapai $61,11 \%$, siklus II mencapai $72,22 \%$, siklus III mencapai $77,77 \%$. Kemampuan dalam menanggapi pertanyaan siklus I mencapai 50,00\%, siklus II mencapai 72,22\%, siklus III mencapai $83,33 \%$. Kerjasama dalam menanggapi pertanyaan siklus I mencapai $50,00 \%$, siklus II mencapai $66,66 \%$, siklus III mencapai $77,77 \%$.

Ketiga aspek yang diamati selama penelitian tindakan kelas kenaikannya dapat dilihat dalam Tabel 1 dan Gambar 1.

Tabel 1. Kenaikan Aspek Kognitif,Apektif dan Psikomotor Tiap Siklus

\begin{tabular}{|c|c|c|c|c|c|}
\hline No & & Aspek & Siklus I & Siklus II & Siklus III \\
\hline \multirow[t]{2}{*}{1.} & Kognitif & & & & \\
\hline & 0 & Tuntas & $53,125 \%$ & $62,50 \%$ & $81,25 \%$ \\
\hline \multirow[t]{4}{*}{2.} & Apektif & & & & \\
\hline & o & $\begin{array}{l}\text { Suasana pertemuan saat } \\
\text { pembelajaran }\end{array}$ & $64,58 \%$ & $76,54 \%$ & $89,58 \%$ \\
\hline & 0 & Topik yang dibahas & $52,08 \%$ & $71,61 \%$ & $83,33 \%$ \\
\hline & o & Kegiatan yang diikuti & $50,00 \%$ & $70,37 \%$ & $84,375 \%$ \\
\hline \multicolumn{3}{|c|}{ Rata-rata } & $55,55 \%$ & $72,84 \%$ & $85,76 \%$ \\
\hline & Psikomo & & & & \\
\hline & o & Kebenaran isi & $72,22 \%$ & $77,77 \%$ & $88,88 \%$ \\
\hline & ○ & Kejelasan suara & $61,11 \%$ & $83,33 \%$ & $88,88 \%$ \\
\hline & ○ & Keruntutan penyampaian & $61,11 \%$ & $72,22 \%$ & $77,77 \%$ \\
\hline & o & $\begin{array}{l}\text { Kemampuan menanggapi } \\
\text { pertanyaan }\end{array}$ & & & \\
\hline & o & $\begin{array}{l}\text { Kerjasama dalam } \\
\text { menanqaapi pertanvaan }\end{array}$ & $50,00 \%$ & $72,22 \%$ & $83,33 \%$ \\
\hline & & & $50,00 \%$ & $66,66 \%$ & $77,77 \%$ \\
\hline \multicolumn{3}{|c|}{ Rata-rata } & $58,88 \%$ & $74,44 \%$ & $83,37 \%$ \\
\hline
\end{tabular}

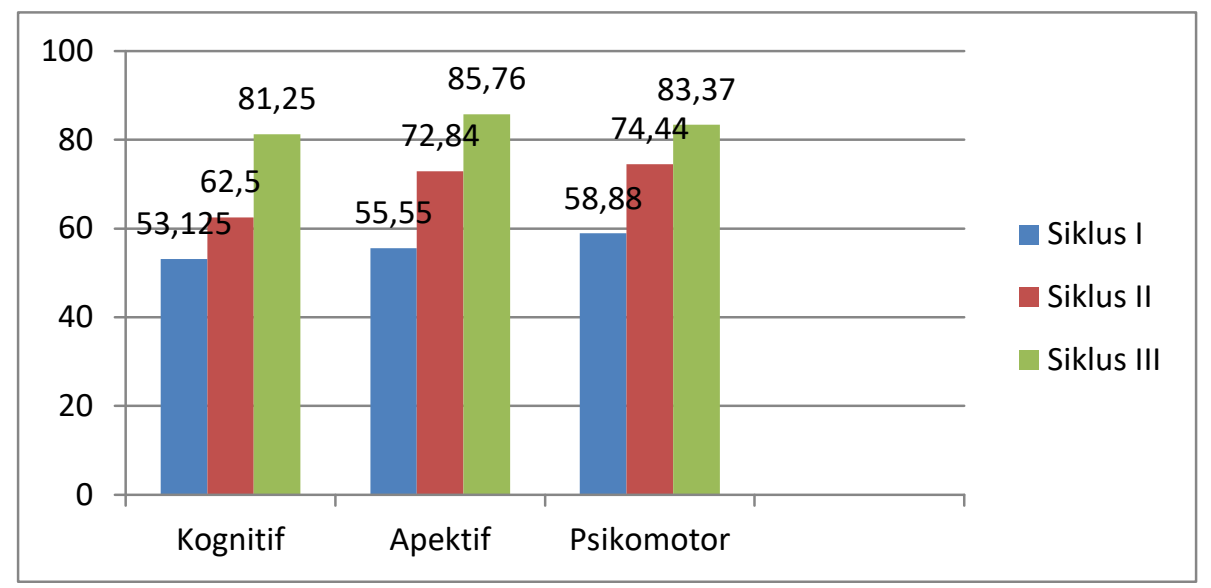

Gambar 1. Kenaikan Aspek Kognitif, Apektif dan Psikomotor Tiap Siklus 
Pada awal kegiatan pembelajaran peserta didik nampak kurang tertarik dengan tema yang di sampaikan, yaitu tentang pencemaran lingkungan, pemahaman sebagian peserta didik baru terlihat ketika disajikan carta tentang pencemaran lingkungan.

Di siklus II di saat kegiatan awal pemahaman peserta didik sudah terlihat, peserta didik seperti ingin mengulang kembali apa yang telah dilakukan di siklus I, saat dilakukan apersepsi dan disampaikan tujan pembelajaran mereka kelihatan sudah dapat menentukan langkah apa yang akan dilakukan. Dalam kegiatan siklus III peserta didik bukan hanya terlihat pemahamannya sejak awal pembelajaran tetapi nampaknya sudah memahami apa yang harus dilakukan selama kegiatan proses pembelajaran. Hasil penelitian ini sejalan dengan penelitian Noma et al., (2016) menunjukkan bahwa pembelajaran Biologi yang menerapkan model PBL pada materi pencemaran lingkungan mampu meningkatkan kemampuan berpikir tingkat tinggi peserta didik kelas X MIA 3 SMA Negeri 2 Sukoharjo. Senada juga dengan hasil penelitian lonita (2020) yang menyimpulkan bahwa model Problem Based Learning berpengaruh positif dan signifikan terhadap kemampuan pemecahan masalah biologi siswa pada materi pencemaran lingkungan di kelas X MIA SMA Negeri 13 Medan Tahun Pembelajaran 2018/2019. Hasil belajar siswa yang diajar menggunakan model Problem Based Learning lebih baik daripada yang diajar dengan pendekatan saintifik.

\section{KESIMPULAN}

Berdasarkan hasil penelitian yang penulis lakukan maka dapat disimpulkan model Problem Based Learning dapat meningkatkan pemahaman peserta didik kelas VII-B SMPN 3 Manonjaya semester genap tahun pelajaran 2018/2019 pada materi pencemaran lingkungan. Hal ini ditunjukkan melalui peningkatan pada beberapa aspek, diantaranya:

a. Peningkatan dalam aspek kognitif, dibuktikan dengan adanya peningkatan prosentase peserta didik yang mencapai KKM.

b. Peningkatan aspek apektif selama peserta didik bekerja kelompok membuat laporan.

c. Peningkatan aspek psikomotor pada saat peserta didik melakukan presentasi hasil kerja kelompok

d. Menumbuhkan kebiasaaan peserta didik untuk dapat membangun sendiri pengetahuan, menemukan sendiri konsep untuk meningkatkan pemahaman materi dan peserta didik mampu belajar secara kelompok.

\section{REKOMENDASI}

Sebaiknya guru atau peneliti lebih kreatif dalam memilih dan menentukan model pembelajaran yang disesuaikan dengan tujuan yang ingin dicapai, bahan materi pelajaran, juga kondisi dari peserta didik.

\section{UCAPAN TERIMA KASIH}

Penulis mengucapan terima kasih kepada siswa 32 orang kelas VII SMP N 3 Manonjaya semester genap tahun pelajaran 2018/2019 yang terdiri dari 18 orang laki-laki dan 14 orang perempuan. Kepada Ibu Teni Sri Erniawati guru mata pelajaran IPA kelas IX selaku observer.

\section{DAFTAR PUSTAKA}

Fauziah, R., Ade, G. A., \& Dadang, L. H. (2014). Pembelajaran saintifik elektronika dasar berorientasi pembelajaran berbasis masalah, Jurnal Invotec, 9(2), 165-178.

Ionita, F. (2020). Pengaruh model Problem Based Learning terhadap kemampuan pemecahan masalah materi pencemaran lingkungan siswa sma negeri 13 medan. JURNAL BIOLOKUS, 3 (1), 245-251.

Noma, L. D., Prayitno, B. A., \& Suwarno. (2016). Penerapan model Problem Based Learning (pbl) pada materi pencemaran lingkungan untuk meningkatkan kemampuan berpikir tingkat tinggi 
peserta didik kelas x mia 3 sma negeri 2 sukoharjo tahun pelajaran 2015/2016. Jurnal BioPedagogi, 5(2), 15-20.

Rahman, L. L., Rusyana, A \& Yulisma, L. (2021). Pengaruh Model Pembelajaran Discovery learning Berbasis LKS Tipe Word square terhadap Keterampilan Berpikir Kritis Siswa. J-KIP (Jurnal Keguruan dan IImu Pendidikan), 2 (1), 33-38.

Rerung, N., Iriwi, L. S., Sri, W. W. (2017). Penerapan model Problem Based Learning (pbl) untuk meningkatkan hasil belajar peserta didik sma pada materi usaha dan energi, Jurnal IImiah Pendidikan Fisika Al-Biruni, 6(1), 47-55.

Saputri, D. A., \& Febriani, S. (2017). Pengaruh model Problem Based Learning(pbl) terhadap kemampuan pemecahan masalah peserta didik pada mata pelajaran biologi materi pencemaran lingkungan kelas $\mathrm{x}$ mia sma $\mathrm{n} 6$ bandar lampung. BIOSFER Jurnal Tadris Pendidikan Biologi, 8 (1), 40-52. 